International Research Journal of Management, IT \& Social Sciences
Available online at https://sloap.org/journals/index.php/irjmis/
Vol. 6 No. 5, September 2019, pages: 53 59
ISSN: 2395-7492
https://doi.org/10.21744/irjmis.v6n5.701

\title{
Application of Diagnostic Assessment on Beginning School Year
}

\author{
Diego Faraday Intriago Conforme a \\ Aminta Lourdes Chunga Romero ${ }^{b}$ \\ Deidal Chunga Romero ${ }^{c}$ \\ Esthela María San Andrés Laz ${ }^{\mathrm{d}}$
}

Article history:

Received: 18 March 2019

Accepted: 31 May 2019

Published: 20 August 2019

\section{Keywords: \\ decision-making; diagnostic evaluation; learning; teacher responsibility; teaching;}

\begin{abstract}
The research aims to determine the degree of effectiveness, relevance, and responsibility in the diagnostic test at the beginning of the school year, for which the opinion of different authors related to the subject, was taken as a reference. Within the methodology, a survey has applied to the teachers of the School of Basic Education "PICHINCHA" of Canton May 24, Parousia Sucre, using the synthetic scientific and analytical method; from which the theoretical elements related to the evaluation of learning were deepened. The results showed that teachers apply the diagnostic test at the beginning of the school year, using evaluation methods and strategies that are used to measure knowledge, during the teaching-learning process, the teacher being able to apply feedback strategies according to the realities, interest, needs and the environment in which students develop. From the results obtained in the diagnostic evaluation to the students, planning has proposed according to the insufficiencies that they present these. The evaluation allows us to proceed with decision-making and apply academic reinforcement, to help overcome the difficulties that arise in the teaching-learning process.
\end{abstract}

2395-7492@ Copyright 2019. The Author. This is an open-access article under the CC BY-SA license (https://creativecommons.org/licenses/by-sa/4.0/) All rights reserved.

\section{Author correspondence: \\ Diego Faraday Intriago Conforme, \\ Masters student the Pontifical Catholic University of Ecuador, Manabí-Portoviejo. \\ Email address: dintriagoc@yahoo.es}

\section{Introduction}

In recent years, there is growing concern about having a quality education in the teaching-learning process. The research carried out seeks that the teacher of the General Basic School "Pichincha", of the Canton May 24 of the Sucre Parish, reflect on the importance of applying the diagnostic evaluation, to the students of the Elementary Basic level (second, third and fourth grade), to improve the quality of teaching.

${ }^{a}$ Pontifical Catholic University of Ecuador, Portoviejo, Ecuador

${ }^{\mathrm{b}}$ Pontifical Catholic University of Ecuador, Portoviejo, Ecuador

${ }^{c}$ Pontifical Catholic University of Ecuador, Portoviejo, Ecuador

${ }^{\mathrm{d}}$ Universidad Técnica de Manabí, Portoviejo, Ecuador 
According to the Organic Law of Intercultural Education (LOEI), the diagnostic evaluation allows knowing the strengths and weaknesses that students have when starting the new school year, in this way, to show the results to make the best decisions (National Assembly, 2011). This document refers that it is necessary and at the same time essential that the results of the diagnostic evaluation serve to be able to recognize the styles and rhythms of learning of each student and thus be able to draw assertive strategies in this regard. Decisions that will have reflected in the different schedules that are required to be used during the development of an apprenticeship, remembering that each student acquires a certain knowledge independently, linked to their interests and their level of understanding.

For this reason, it should have considered that the results of the diagnostic evaluation allow:

a) Reflecting the way in which the teacher relates and selects the contents considering the preferences and interest of each of the children in their classroom.

b) Analyze how the new knowledge that is going to work in classes will be realized with the interest of the students in such a way that it can satisfy the need to learn from the group; At the same time, it allows:

c) To take into consideration which topics are more extensive and which topics are more relevant to the common interests of the group of students at the time of developing the tasks.

The diagnostic evaluation, is one of the necessary processes, that is carried out to measure what students have achieved, from the moment they enter school until the end of their school year (Cano, 2005), it indicates that evaluation is the process of examining something, and first knowing the object to be evaluated, which involves and involves tasks through social research and dissemination techniques, allowing actors to be responsible for the evaluation study.

Within a school process it is important to carry out a diagnostic evaluation to define the competencies that the student has at the beginning of the school year (Santos, 1993; Maba et al., 2018), it refers that the educational evaluation is a phenomenon usually limited to students and to the control of students. knowledge acquired through various types of tests.

In the traditional evaluation the teachers are based on applying a qualification without taking into account the potential of the students, this evaluation makes it difficult for the student to be creative, participatory and innovative (Condemarín et al., 2000), states that the traditionalist teacher is the owner of the knowledge he imparts to students and does not give them the opportunity to develop their skills and abilities, measuring their knowledge through a written and oral test in this memorial way. The authentic or formative evaluation is the success of the student's participation from the moment the evaluation process begins, valuing the previous knowledge and their abilities, allows them to be encouraged to be participants in their learning, critical and analytical of their own knowledge.

The teaching work involves a systematic and sequential series of processes and procedures planned in advance to be able to apply one or more contents during teaching. The diagnostic evaluation is a study that aims to measure the level of cognitive development that students have achieved in basic skills (Vargas \& Ubieta, 2009), indicate that the planning is focused on the interests of students individually and Collective, obtaining better results compared to planning not suitable for a specific learning environment, this lies in the mistaken belief of the teaching experience when working with groups of students of the same educational level, of the same age and with learning difficulties.

Through the proper application of the evaluation the teacher will obtain valuable information from the student, as he argues (Sanchez, 2016; Mahendra, 2016), that the results obtained from a certain process should not only be applied at the beginning of a new class or at the end of a didactic unit, but taking into consideration the application of summative evaluations, they present with greater notoriety the results of a work carried out without the proper planning or diagnosis of a group.

In the daily pedagogical practice, one of the complex moments in which teachers are immersed, in the affirmative decision-making process to improve the quality of teaching, is applying different tools and strategies to improve meaningful learning but deciding which one is the most appropriate and the one that will give the best result for student learning (Fonseca, 2011; Dewi, 2018), states that feedback should accompany teaching-learning throughout the process with the intention of giving immediate and timely information to the student about the quality of their performance in order to improve their competence and that the teacher delegates time to the elaboration of their planning to review the contents that students must develop and acquire basic and fundamental knowledge in a given subject.

The teacher modifies the strategies applied in the class to motivate the acquisition of new knowledge in a dynamic and harmonious way to the pace of student learning (Gorozabel, 2014; Suastra \& Ristiati, 2017), refers that the feedback expresses opinions, judgments based on the learning process, with hits and misses; strengths and weaknesses of the students. 
Through feedback strategies, not only is it sought to improve pedagogical practice, but to obtain the best results within the school training process with the objective of determining the degree of effectiveness, relevance and responsibility in the diagnostic test at the beginning of the school year and of that Professional preparation way for the future.

\section{Materials and Methods}

The research was carried out at the Basic General School "PICHINCHA" of Canton May 24, Parroquia Sucre, using the technique of surveys of teachers working in said Institution, the synthetic scientific and analytical method was used from the deepened the theoretical elements concerning the evaluation of learning using the equation (1).

$$
n=\frac{\left(Z^{2}\right)(P)(Q)(N)}{\left(Z^{2}\right)(P)(Q)+(N)\left(e^{2}\right)}
$$

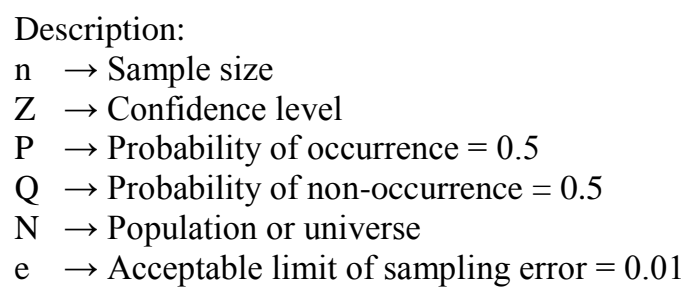

\section{Results and Discussions}

The well-planned diagnostic evaluation and implemented by the teachers of the General Basic School "Pichincha" of the canton May 24 of the Sucre parish, allows to obtain valuable information regarding the cognitive level of students at the beginning of a school period, the result of this test identifies different realities and needs about the achievements obtained by the students at the end of the school year and at the beginning of the next period, as stated by Sánchez, (2016; Anthony et al., 2017), these results expose the level of competence achieved by the student during the term of a curriculum.

Figure 1 shows the results obtained in interviews with teachers, related to the type of diagnostic evaluation they apply to their students, it is observed that $80 \%$ of respondents gave the answer that the application of the diagnostic test is written, In this way, obtaining reliable data when analyzing the results for making assertive decisions with each of the students according to their needs and interests.

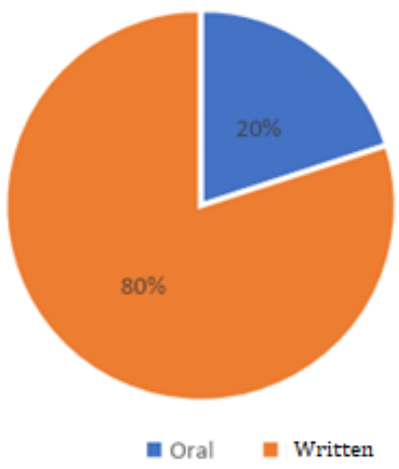

Figure 1. Type of diagnostic evaluation

Source: Pichincha Basic General School

Conforme, D. F. I., Romero, A. L. C., Romero, D. C., \& Laz, E. M. S. A. (2019). Application of diagnostic assessment on beginning school year. International Research Journal of Management, IT and Social Sciences, 6(5), 53-59. https://doi.org/10.21744/irjmis.v6n5.701 
According to what is indicated by Soria (2012), in relation to the feedback process implemented along with the diagnostic evaluation, it is possible to maximize the significant learning of the students, the application of these activities by the teachers of this Educational Center, it shows negative results for some cases, since in others it does not have the same level of effectiveness due to the participation of the family in the student learning process during the previous school year.

In figure 2, according to the data obtained on the moment of application of the diagnostic test, $90 \%$ of the respondents consider that it should be applied at the beginning of the teaching-learning process, in order to determine the knowledge previous students related to their school training, obtaining good results during the process.

- At the beginning of the teaching-learning process' - 'During the teaching learning process

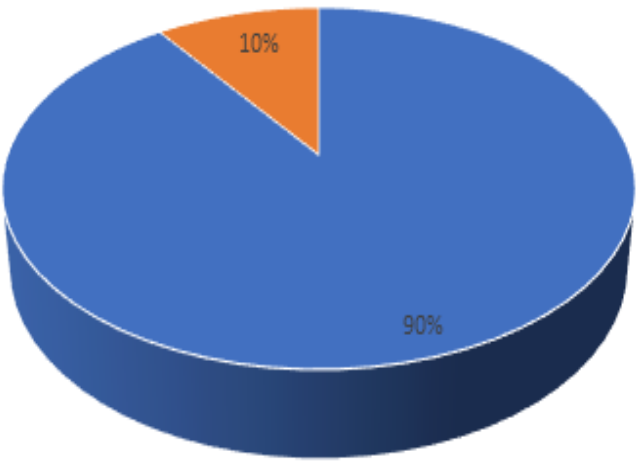

Figure 2. Diagnostic test

Source: Pichincha Basic General School

The way in which the teacher adapts the diagnostic evaluation depends on the approach and the purpose for which it is applied, the objective of the same must be elaborated in order to identify according to the educational reality, the interests and needs of children, in the rural sector there are many limitations, in addition the family environment significantly influences the results of the teaching-learning process and the strategies that the teacher applies during the development of his class.

In figure 3, the results obtained are observed, when consulting teachers about The diagnostic evaluation, if applied only to know the level of knowledge that students have at the beginning of the teaching-learning process, $70 \%$ of respondents stated that these diagnostic tests should be performed, which is considered a reality in the workplace $30 \%$ believe that it must be applied at other times.

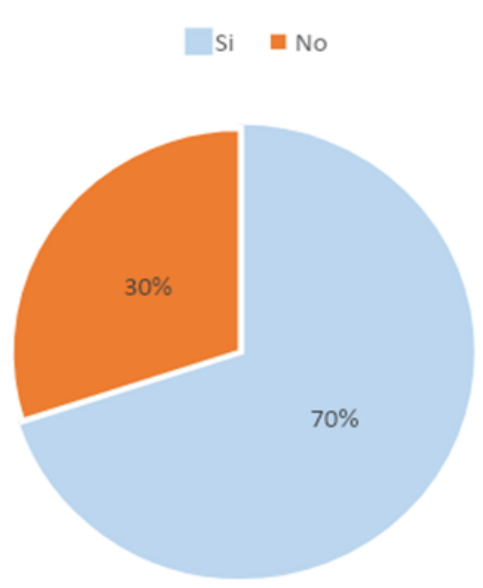

Figure 3. Consult the teachers about the objectives of the diagnostic evaluation 
The evaluation is a process where information about the learning and teaching that students have acquired will be known, helping the teacher to make the corresponding decisions to the improvement of the student (González \& Pérez, 2004; Wartawan, 2017), refers that the evaluation is a reflection, a quality control on what is done, and then make the decision making.

In figure 4, the results are shown, in the survey conducted to teachers if they adequately plan the diagnostic evaluation, before starting a unit or subject, $60 \%$ said that if they carry out the planning considering that it should be developed before starting a new unit, $40 \%$ said it does not carry out a previous planning; but he considers that the results obtained from the diagnostic evaluation allow planning then the strategies and tools of feedback necessary to strengthen the knowledge in the students.

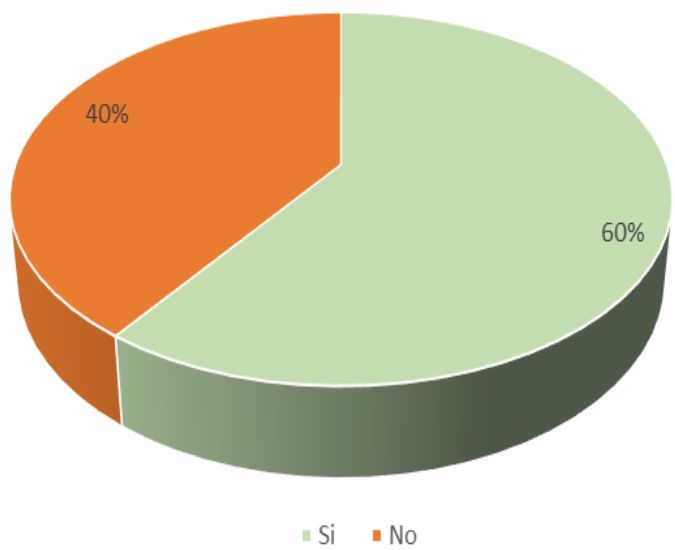

Figure 4. Consultation at which moment the diagnostic evaluation

When applying the diagnostic evaluation the teacher manages to identify the degree of certainty of the students' knowledge about a certain subject or what most of them know, also needs to develop skills to understand new issues, this way you can properly structure the schedules.

In figure 5 , the results obtained in the survey of teachers in relation to the activities they plan after the application of the diagnostic evaluation are observed, $40 \%$ of respondents say that they carry out reinforcement activities, $30 \%$ prepare Review activities to encourage meaningful learning in students so that students consolidate their knowledge at the end of the learning cycle, $10 \%$ do accommodation activities and $20 \%$ do not plan any activity after applying the diagnostic evaluation

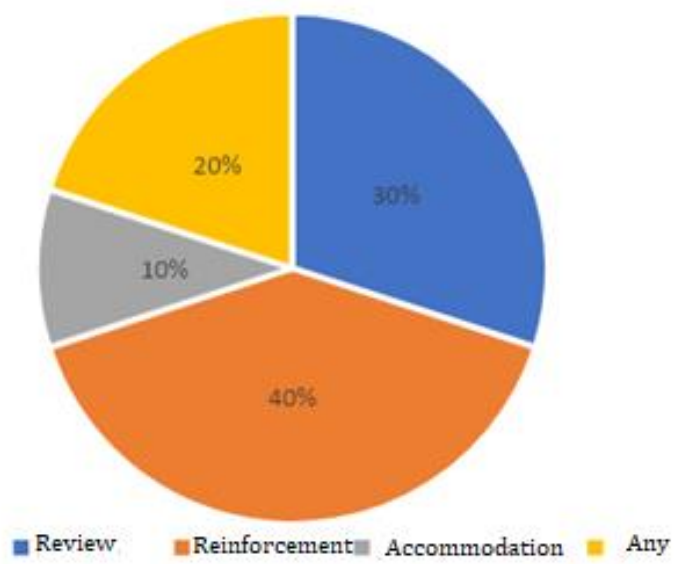

Figure 5. Activities planned after the diagnostic evaluation

Conforme, D. F. I., Romero, A. L. C., Romero, D. C., \& Laz, E. M. S. A. (2019). Application of diagnostic assessment on beginning school year. International Research Journal of Management, IT and Social Sciences, 6(5), 53-59. https://doi.org/10.21744/irjmis.v6n5.701 
The diagnostic tests applied by the teachers of the basic years of the "Pichincha" Basic General School of the canton May 24 of the Sucre parish, have a wide degree of effectiveness in identifying the needs of students at the beginning of the school year, inadequacies that cover subjects in the areas of mathematics and language, basic components of the significant learning that the student must possess at the end of a school period.

\section{Conclusion}

When analyzing the results obtained from the application of diagnostic tests, the teacher develops feedback strategies according to the reality, interest and needs of students whose diagnostic test yields as a result that they need an academic reinforcement, for this reason, The teacher performs accompaniment to help the child overcome the difficulties that arise in the learning process.

The most common learning needs to be detected in the children of the educational center, lies in the lack of support of parents and legal representatives in the development of homework and supervision of schoolwork at home, added to this the level The socio-economic status of this parish influences that in the afternoons some children have to do housework, which leaves time to complete the school tasks.

Conflict of interest statement and funding sources

The authors declared that they have no competing interest.

Statement of authorship

The authors have a responsibility for the conception and design of the study. The authors have approved the final article.

Acknowledgments

The authors thank the editor of IRJMIS for their valuable time, support, and advice in completing the current study. 


\section{References}

Anthony, K. A., Oshoke, S., \& Slyvester, O. (2017). Assessment of entrepreneurial education and diversity management: a gateway to sustainable development in Nigeria. International Research Journal of Management, IT and Social Sciences, 4(1), 53-60.

Cano, A. (2005). Topic 5: aspects for an evaluation definition. https://www2.ulpgc.es/hege/almacen/download/38/38196/tema_5_elementos_para_una_definicion_de_evaluacio n.pdf

Condemarín, M., and Medina, A. (2000). Learning Evaluation. http://ww2.educarchile.cl/UserFiles/P0001/File/Evaluacion_Apredizajes.pdf

Dewi, K. T. (2018). Developing assessment instrument based curriculum 2013 for teaching micro teaching in English education department of Undiksha. International Journal of Social Sciences and Humanities, 2(3), 95-106. https://doi.org/10.29332/ijssh.v2n3.205

Fonseca, H. (2011). Feedback during the teaching-learning process. Mexico. http://www.imbiomed.com/1/1/articulos.php?method=showDetail\&id_articulo=71932\&id_seccion=4304\&id_eje mplar=7186\&id_revista $=271$

González, M., Pérez, N. (2004). The evaluation of the teaching-learning process. Fundamentals

Gorozabel, T. (2014). The importance of Feedback in the Process Evaluation. http://umc.minedu.gob.pe/laimportancia-de-la-retroalimentacion-en-el-proceso-de-evaluacion/

Maba, W., Perdata, I. B. K., Astawa, I. N., \& Mantra, I. B. N. (2018). Conducting assessment instrument models for teacher competence, teacher welfare as an effort to enhance education quality. International Research Journal of Management, IT and Social Sciences, 5(3), 46-52.

Mahendra, I. W. E. (2016). Contextual learning approach and performance assessment in mathematics learning. International Research Journal of Management, IT and Social Sciences, 3(3), 7-15.

National Assembly. (2011). ORGANIC LAW OF INTERCULTURAL EDUCATION. Montecristí. Montecristi, Ecuador. $\quad$ https://educacion.gob.ec/wp-content/uploads/downloads/2017/05/Ley-Organica-EducacionIntercultural-Codificado.pdf

Sánchez, V. (2016). Results of the diagnostic evaluation. Medellin, Colombia: new Horizons.https://www.tdx.cat/bitstream/handle/10803/1311/08.ACL_CAP_7.pdf?sequence=9\&isAllowed=y

Santos, M. (1993). Evaluation: a process of dialogue, understanding and improvement. Magazine

Soria, E (2012). www.fod.ac.cr. Retrieved on April 20, 2019,

Suastra, I. W., \& Ristiati, N. P. (2017). Problems faced by teachers in designing and implementing authentic assessment in science teaching. International Research Journal of Engineering, IT \& Scientific Research, 3(4), $27-36$.

Vargas, A., \& Ubieta, E. (2009). Diagnostic evaluation report. Barcelona, Spain: Ocampo. http://ediagnostikoak.net/edweb/cas/materiales informativos / ED09_inf_gnal_rdos / ED09_2ESO_inf_gnal_rdos.pdf

Wartawan, P. G. (2017). The effectiveness of the use of portfolio assessment by controlling prior knowledge to enhance scientific attitude among senior high school students. International Journal of Physical Sciences and Engineering, 1(3), 9-18. https://doi.org/10.21744/ijpse.v1i3.54

Conforme, D. F. I., Romero, A. L. C., Romero, D. C., \& Laz, E. M. S. A. (2019). Application of diagnostic assessment on beginning school year. International Research Journal of Management, IT and Social Sciences, 6(5), 53-59. 